JURNAL ILMIAH MANAJEMEN BISNIS DAN INOVASI UNIVERSITAS SAM RATULANGI

\title{
THE INFLUENCE OF COUNTRY IMAGE, BRAND FAMILIARITY, PRODUCT QUALITY, AND SOCIAL INFLUENCE TOWARDS PURCHASE INTENTION: THE CASE STUDY OF SAMSUNG
}

\author{
Michael Rusiviro Jacob, Pauline Henriette Pattyranie Tan
}

Universitas Pelita Harapan

A R T I C L E I N F O

Keywords: International business, global marketing, consumer behaviour, purchase intention, country image, product quality, brand familiarity, social influence

\section{Kata Kunci: Bisnis internasional, pemasaran global, perilaku konsumen, niat membeli, citra negara, kualitas produk, keakraban merek, pengaruh sosial} Corresponding author:

Pauline Henriette Pattyranie Tan pauline.henriette@uph.edu
Abstract: The smartphone industry has grown rapidly in recent years, and one of the market leaders is Samsung. Over the past few years, Samsung has been remaining as the top brand in the smartphone industry worldwide and has maintained its market share in the world. However, this is not the case in Indonesia. In recent years, Samsung in Indonesia has also experienced a dwindling market share, that is why it is interesting to conduct in-depth research on its consumer purchase intentions. Therefore, this study utilizes Country Image, Product Quality, Brand Familiarity as independent variables to explore their influence on Samsung smartphone purchase intentions to examine the nature of Samsung's consumer purchase intentions and then to provide some recommendations on how Samsung can increase its market share in Indonesia. This study used primary data by using convenience sampling. The data analysis used Structural Equation Modeling (SEM) through SmartPLS and the results showed that Product Quality, Brand Familiarity, and Social Influence had a positive and significant effect on Purchase Intention, while the State Image proved insignificant.

Abstrak: Industri smartphone telah berkembang pesat dalam beberapa tahun terakhir, dan salah satu pemimpin pasarnya adalah Samsung. Selama beberapa tahun terakhir, Samsung telah bertahan sebagai merek teratas dalam industri ponsel pintar di seluruh dunia dan telah mempertahankan pangsa pasarnya di dunia. Namun tidak demikian halnya di Indonesia. Dalam beberapa tahun terakhir, Samsung di Indonesia juga mengalami pangsa pasar yang semakin menipis, oleh karena itu menarik untuk dilakukan penelitian mendalam tentang niat beli konsumennya. Oleh karena itu, penelitian ini memanfaatkan Country Image, Kualitas Produk, Brand Familiarity sebagai variabel independen untuk mengeksplorasi pengaruhnya terhadap niat beli smartphone Samsung untuk mengetahui sifat niat beli konsumen Samsung dan kemudian memberikan beberapa rekomendasi bagaimana Samsung dapat meningkatkan pangsa pasarnya di Indonesia. Penelitian ini menggunakan data primer dengan menggunakan convenience sampling. Analisis data menggunakan Structural Equation Modeling (SEM) melalui SmartPLS dan hasil penelitian menunjukkan bahwa Kualitas Produk, Keakraban Merek, dan Pengaruh Sosial berpengaruh positif dan signifikan terhadap Niat Membeli, sedangkan Citra Negara terbukti tidak signifikan 


\section{INTRODUCTION}

In globalization era, activities around the world has experienced progressive developments and evolvement processes especially in international business activities. International business has enabled trading in business activities across nations and it has also affected the creation of multinational corporations. One of the factors that driven this development in international business is the reduction of boundaries in many markets, not only domestically, but also internationally. The expansion of market potential abroad has led companies to sell their product abroad. As more companies start to sell their products abroad, the number of foreign brand products increased in various markets. This phenomenon has affected consumers buying behavior, whereas consumers become more evaluative towards a product when considering to buy a product. The development in international business has not only affected trade across borders internationally, it also affected the flow of information across the world.

The need for information has increased over time. In order to get the information that is needed, there are some ways that can be used such as browsing the web, reading books that contain relevant information that is needed, and through communication on smartphones. In the beginning, smartphones were made specifically to communicate with voice through signals, but nowadays, smartphones can help its user in many ways, from opening global sources of information, bridging the gap in communication through online messaging, e-mails, photos, videos, monitoring health, finance, or even studies, smartphones can almost do it all (Device Region, 2017). The progressive advancement of smartphones technology has enabled smartphones to evolve and become a computer like technology. Hence, its capability has made smartphones to become an essential tool for consumers in order to perform daily personal and professional operations.

Therefore, according to Statista (2020) the number of smartphone users worldwide has increased in the course of 4 years. From 2016 to 2019, worldwide smartphones users have increased from 2.5 billion people to 3.5 billion people. It is also estimated that by 2021, the number of worldwide smartphones users will go up to approximately 3.8 billion (Figure 1.1). This increased of smartphone users worldwide is also occurred in Indonesia, according to Statista (2020) from 2010 to 2018, the percentage of Indonesian people that use smartphones has gone up from $38.05 \%$ to $62.41 \%$ in the course of 8 years (Figure 1.2). For several years, Samsung has been a top contender in smartphone market all over the world. In fact, from 2016 until 2019, Samsung managed to improve their market share in the last year of 2019 , by $0.46 \%$ compared to 2018 (Table 1.1). This positive growth in 2019 indicated a slight uptrend of Samsung market share in the world.

Table 1.1 Mobile Phone Market Share by Vendor in the World

Smartphones Brands

Des $2016 \quad$ Des $2017 \quad$ Des 2018

(in percentage)

\begin{tabular}{ccccc}
\cline { 2 - 4 } Samsung & 33.63 & 31.65 & 30.91 & 31.37 \\
Apple & 18.89 & 19.91 & 21.98 & 24.79 \\
Huawei & 3.68 & 4.96 & 7.52 & 9.95 \\
Xiaomi & N/A & 4.75 & 8.44 & 7.73 \\
Oppo & N/A & 3.42 & 4.87 & 4.23 \\
Mobicel & N/A & N/A & 3.3 & 3.19 \\
\hline
\end{tabular}

Source: Statcounter (2020)

In Indonesia, Samsung still held the title as the market leader in the smartphone industry. In 2019, it held approximately $24.22 \%$ market share of smartphone industry in Indonesia (Table 1.2). Although, Samsung still held the title of the market leader of Indonesia's smartphone industry in 2019, there has been a declining trend of Samsung market share in the Indonesia's smartphone industry from 2016-2019 period, where the overall market shared of Samsung declined from $29.54 \%$ in 2016 to $24.22 \%$ in 2019 or has 
plummeted over 5\% in the course of four year periods, whereas the market shares of smartphone companies like Oppo and Xiaomi from China were increasing rapidly. From 2016-2019 period, Oppo managed to increase their market share in Indonesia by $13.55 \%$, whereas Xiaomi managed to increase their market share in Indonesia by $14.67 \%$ (Table 1.2).

Table 1.2 Mobile Phone Market Share by Vendor in Indonesia

\begin{tabular}{cccc} 
Smartphone Brands & Des 2016 & $\begin{array}{c}\text { Des 2017 } \\
\text { (in percentage) }\end{array}$ & Des 2018 \\
\hline
\end{tabular}

\begin{tabular}{ccccc} 
Samsung & 29.54 & 29.32 & 25.98 & 24.22 \\
Oppo & 6.6 & 11.52 & 16.9 & 20.15 \\
Xiaomi & 6.57 & 15.29 & 21.39 & 21.24 \\
Nokia & 8.19 & 2.57 & 1.3 & N/A \\
Apple & 4.09 & 3.84 & 5.85 & 6.38 \\
Mobicel & N/A & N/A & 6.22 & 10.6 \\
Unknown & 20.47 & 15.29 & 10.17 & 4.35 \\
\hline
\end{tabular}

Source: Statcounter (2020)

Market share can also be seen as sales that relative to other smartphone manufacturer in the industry and it is used to express competitive position in the market (Etale, Bingilar, Ifurueze, 2016). According to Morwitz (2012) purchase intention is the leading indicator in measuring future demand of a product and it helps to assess the actions needed to improve future sales. Therefore, to measure future demand of the product and to assess the actions needed to improve future sales it is important to analyse the consumer purchase intention.

\section{LITERATURE REVIEW}

International Business, Global Marketing, and Consumer Behaviour

A fundamental change in the world economy has made the world move away from a world that emphasize on national economies that tend to be more self-contained entities, towards a world in which all of the barriers in cross border investments and cross-border trades are diminishing, in which national economy are integrated into a more interdependent, integrated global economic system or as commonly known as globalization (Hill, 2007, p.4). Globalization can be inferred as the unavoidable markets, nations, and technologies integrations, that enables individuals, nations-states, and corporations to reach the other parts of the world in a faster, farther, cheaper, and deeper manner than ever before (Griffin \& Pustay, 2015, page 34). This further expansion allows small and big companies to increase their profit and achieve greater sales by operating internationally through transfer of their capabilities to international markets (Tien, Phu, Chi, 2019). International markets are likely to present more potential than the domestic market alone, this is due to the fact that international markets are wide in scope, varied in consumer tastes, preferences and purchasing abilities, size of the population etc. (Rao, 2008, page 5).

In the past decade, many experts believe that the world has arrived in the globalization era that affected the rapid growth of international business. Hence, international business can be defined as business transactions that occur between various parties such as individuals, companies, a group of companies, and or government agencies that come from more than a single country (Griffin \& Pustay, 2015, p.28-34). International business has a strong connection with international marketing, because the term international business has emerged from a more specific term which is international marketing (Sinha \& Mittal, 2012, p.3).

International marketing can be defined as business activities performance that is designed to plan, promote, price, and direct the flow of goods and services of the company to customers in more than one 
country for profit (Cateora, Gilly, Graham, 2011, p.10). One of the aspects of international marketing is global marketing (Tien, et al., 2019). Global marketing can be defined as marketing activities that are integrated and coordinated across multiple markets in multiple countries (Johansson, 2009, p.14). The integration might involve uniform packaging, synchronized product introductions, identical brand names, standardized products, similar advertising messages, and coordinated sales campaigns across multiple markets in various countries. The term global doesn't imply that most of the countries in the world have to be included, even regional marketing can be considered as global marketing as well.

The only key difference between global marketing and regular marketing is that organizations that involve in marketing on a global scale tend to focus their resources and competencies in order to overcome threats that occur in global markets. Thus, the fundamental difference between global and regular marketing is the scope of both activities. As a general whether it is global or regular, marketing is the function of organization and a set of processes that is used for communicating, creating, and delivering value to consumers in order to manage customer relationships that will benefit the organizations and its stakeholders (Keegan \& Green, 2011, p.38).

Marketing has sets of strategies to help organizations manage and allocate its marketing resources to effectively achieve profit in the long run (Nugroho \& Irena, 2017). In order to create effective marketing strategies, organizations need to consider marketing mix that acts as controllable variables that will help them develop effective marketing strategies. Furthermore, this marketing mix is generally known as $4 \mathrm{ps}$ that includes product, price, place, and promotion. Although 4ps in theory is important, it is no longer enough because $4 \mathrm{ps}$ is considered to be more towards the marketing activity rather than the consumer itself, therefore consumer behaviour is a relevant aspect that needs to be considered. Hence, Nugroho and Irena explained that the study of consumer behaviour will help marketers to understand not only the products that consumers purchase, but the reason behind their intention and decision to purchase the products.

\section{Theory of Reasoned Action and Purchase Intention}

Reasoned action theory explained that the comprehensive integration of attitude attributes into a model can be used to give a result of better explanation and a better predictions of consumer behavior. It also combined three aspects which are cognitive, affective, and conative aspects in order to better understand about intention with the addition of subjective norms that influenced an individual's intention to act in a certain manner. Subjective norms can be measured by assessing the influence that others have towards their behavior (Schiffman \& Kanuk, 2007). This theory suggests that attitudes will have an influence to intentions because as attitude towards a product increase, the intention to buy the product will likely to increase as well (Kardes, Cronley, Cline, 2008).

Purchase intention is the evolution of the term intention, which intention itself is the subjective probability that a person performs a particular choice of action or it is well known as a plan that influence and instruct a person to behave in a certain way and implies in the way of "I will do", "I am going to do", and "I should do" (Kian, Boon, Fong, Ai, 2017). Purchase intention is considered as one of the consumers' cognitive behaviour elements that reveals the way an individual intends to purchase a certain brand, in which purchase intention is used to predict what products consumers will purchase. Purchase intention can be defined as preferences that consumers have for purchasing a product or service. (Younus, Rasheed, Zia, 2015).

Purchase intention is classified as the determinant factor of customers' expectations and needs towards a product in order to explore their assessment furthermore on that particular product (Xiao, Yang, Iqbal, 2018). It is also considered to be the key variable that promotes the success of a business in the long-term, which helps to retain customers and collect customer lifetime value. Purchase intention is an effective tool in predicting consumers' buying process (Mirabi, Akbariyeh, Tahmasebifard, 2015). It consists of a wide range combination of studies, but it is basically composed of two studies which are consumer behavior and the consumers' intentions (Curvelo \& Afinito, 2019). The evaluation that consumers have is not only based on intrinsic factors such as product quality, but also extrinsic factors such as country image, brand familiarity, and social influences. The extrinsic product factors are the features in a product that are not part of the product but are influencing and related to the product, meanwhile intrinsic product factors are the 
features of the product that the product itself possessed (Fetai, Sadikhu-Dushi, Ismaili, 2017). Consumers' intentions to purchase a certain product is influenced by many factors and the ultimate decision will depend on the dominant external factors that influenced the consumer (Younus, et al., 2015).

\section{Country Image}

The country of origin has managed to gain an important position for marketers in understanding consumers' behavior specifically in consumer preferences and purchases of foreign products, which the image of country that the product is originated from has a positive effect towards the perception of the brand itself (Haque, Anwar, Yasmin, Sarwar, Ibrahim, Momen, 2015). Thus, country image or commonly known as COI can be defined as the sum of impressions, ideas, and beliefs that consumers have towards a country, and it is represented by the simplification of a large number of information, associations, and indications, that are connected with a place (Herrero-Crespo, Gutierrez, Garcia-Salmones, 2016).

These country images are created through national characteristics, political background, economic background, and country's history (Xiao, Zhang, Li, Samutachak, 2016). Consumers used perceptions and stereotypes about a country as a part of the country image as shortcuts for information processing and heuristics consumer decision. Furthermore, country image is indicated as a "halo effect" from which consumers tend to infer those attributes of products from their perception from its country of origin (Herrero-Crespo, et al., 2016).

According to Augusta, Mardhiyah, and Widiastuti (2019), products that are produced in more developed countries tend to be more accepted than products that are produced in less developed countries, because countries with good country image are considered to produce products with more sophisticated technologies. When consumers had a favorable perception towards a product that originated from a particular country, it will likely to increase the image of a product or brand, on the opposite, a negative image towards a product that originated from a particular country, it will prevent them to purchase a product or a brand from that particular country (Haque, et al., 2015). It has also been proven that country image will have a direct effect towards purchase intention (Haque, et al., 2015).

A study was conducted by Emalia Diah Augusta, Dien Mardhiyah, and Tika Widiastuti in 2019 with the purpose was to analyse the influence that country of origin image had towards purchase intention. In their research, country of origin image acted as an independent variable while purchase intention acted as a dependent variable. The object that they used for the research was a Korean cosmetic product called Etude House in Indonesia. Through the analysis that they have conducted with approximately 213 respondents, the result of their research suggested that country image will positively influence purchase intention. The result showed that the reputation of the advanced beauty industry in Korea helped to convince Indonesian consumers and improve Indonesian consumers' confident to purchase Etude House product because it comes from Korea.

In 2015, Kitto Hananto did a study based on the rapid development of globalization that influenced the growth of smartphones users. One of the goals of this research is to analyze the effect of the image of country of origin on Iphone buying behavior in Malang. Hence, the result from approximately 200 students in Malang showed that the country of origin image has a significant positive effect on the intention in purchasing iPhone among students in Malang. This means that consumers tend to focus more on the country where the product comes from to evaluate the image of the product and it is likely to form their intention to purchase the product. According to Hien, Phuong, Tran, Thang (2020), country of origin image plays an important part in brand image, where country of origin brands will be perceived as prestigious, advanced, and creative in design.

Previous research conducted by Hien, et al. (2020) on electric household appliances in Ho Chi Minh city and Da Nang city from 283 respondents proved that country of origin image has a significant positive impact towards consumers' purchase intention, which indicated that country of origin image plays an important role in consumers' purchasing decisions. Furthermore, customers also are likely to develop their perceptions and beliefs of a brand based on the country of origin of the brand itself and the results reflect consumer's belief in brands that come from developed countries (e.g. Korea, United States, Japan). As a result, they will likely to become more popular and often selected in the purchase decision process. 


\section{Product Quality}

Product can be identified as anything that is physical or not that can be propose to a potential consumer to satisfy their certain wants and needs (Prayogi \& Santosa, 2019). Prayogi and Santosa (2019) also added that product is a whole concept of an object or a proses that give an added value to the consumer, because the consumer will not only buy the product by itself, but also the benefits and values that come with the product itself. Hence, quality can be broadly inferred as excellence or superiority (Razak, Nirwanto, Triatmanto, 2016). Thus, product quality can be defined as characteristics of a product that has ability to satisfy or implied customers' needs. It is mentioned that consumers will be more pleased and satisfied when a product satisfy their expectations, on the contrary consumers will be dissatisfied if the performance of the product does not meet their expectations (Xiao, et al., 2018).

According to Mirabi, et al. (2015) Consumer will be inclined to purchase a product if a product has a better quality. Perceived quality is a general perception of superiority or quality of a product, it is also consumers' intangible feeling about a certain brand that is also based on key dimensions that consist of product specification. Product quality is one of the main factors that is used to assess purchase intention. A study conducted by Mirabi, was intended to find out the factors that affecting purchase intention on Bono brand tile in Tehran. The result that is derived from approximately 384 respondents proved that product quality has a significant positive influence towards purchase intention. The result also proved that product quality was the first factor that affects customers' purchase intention and this proved that product quality is a key factor in the purchase intention of customers because the result showed that product quality has one of the most significant impact towards purchase intention.

Purba, Sulistyarini, and Sadalia (2018) also mentioned that product quality is a combination of nature and characteristic which determines the extent to which an output can meet the customers' needs or assess the extent to which the nature and characteristic fulfil the customers' necessity. Their research conducted on Telkomsel usage in Medan from approximately 100 university students was aimed to identify and analyse the influence of product quality towards purchase intention. The result showed and also proved that product quality has a significant effect towards consumers' purchase intention, and concluded that a good quality can increase the purchase decision of consumers towards a product. This result also in line with previous research which revealed that the eight dimensions framework of quality will ultimately influence consumer purchase behavior.

Furthermore, Erida and Rangkuti (2017) also stated that products with better quality than other products in the same category from other brands would likely to increase consumers' intention to purchase that product. A previous study conducted by Erida and Rangkuti on the overall effect of product quality towards purchase intention of Asus notebooks in Indonesia. The result from 99 respondents conclude that product quality has a significant positive effect towards consumers purchase intention, also based on their observations, it is found that consumers will provide a positive assessment of the quality of hardware towards Asus notebooks based on its durable batteries and notebook cooling system reliable even though it is used in a long period of time and in the room that has no air conditioner. They also found that products with better quality than similar products with other brands would increase consumers' buying intentions over the product.

\section{Brand Familiarity}

Brand familiarity can be defined as accumulated related experiences that consumers have had with a particular brand (Das, 2015). Consumers who are familiar with a brand are inclined to develop more favorable assessments towards purchase intentions of that brand. Das also added that the more familiar a consumer with a brand, the more favorable assessment that consumer will give towards the brand.

Brand familiarity reflects the prior experience that the consumer had both directly and indirectly with the brand which the consumer had stored in their memory (Rhee \& Jung, 2018). Brand Familiarity is not only reflecting the overall prior experiences that consumer had with the brand, but also it is related to the image of the brand and use of the brand, in which brand familiarity is one of the pivotal factors that influences consumers' purchase decision. Brand familiarity emphasizes a customer's prior knowledge about 
a particular brand and their pre-existing knowledge structure will influence how they processed a certain information or input that is related to that particular topic.

Furthermore, the more knowledge that consumers have towards a particular brand, the more capable they can process information in an extensive and systematic way, but the less knowledge that consumers have towards a particular brand, they are likely to process information in a more heuristic way (Huang, 2016). When consumers are exposed to an unfamiliar brand, they tend to use their cognitive resources to process information in order to assess that particular brand, but when consumers are exposed to a familiar brand, the learning goal is no longer important because the consumers know the brand well. Augusta et al. (2019) stated that consumers will have a high closeness to a particular brand if they are familiar with the brand, because the more familiar consumers with a particular brand, the greater the purchase intention towards its products and vice versa.

Das (2015) did a research on brand familiarity towards purchase intention which aimed to explore the direct and indirect impact that brand familiarity had towards purchase intention with the moderation of gender. This research conducted in Kolkata on fashion retail brands from approximately 374 respondents from six fashion retailers: Reliance Trends, Wills Lifestyle, Provogue, Spykar, Brand Factory, and Levi's. The result of the research proved that brand familiarity has a direct significant effect towards purchase intention. Purchase intention may result in actual purchase and it takes a pivotal role in encouraging the sustainability and profitability of fashion retailers and one of the variables that influence purchase intention is brand familiarity.

Another previous study conducted by Viddy, Rafiqoh, Kadang, Angriani (2018) on Yamaha NMAX in Samarinda from 126 respondents proved that brand familiarity had a significant positive effect towards purchase intention. It can occur because most of the respondents were in the age range between 20 to 30 years old and have a middle level of income, furthermore it is easier to find this brand as they feel more familiar with the brand of Yamaha NMAX. Furthermore, a previous study conducted by Augusta et al. (2019) on Korean cosmetic products called Etude House have tried to analyse whether or not brand familiarity has a positive impact towards purchase intention. This research was conducted in Indonesia with approximately 213 respondents. The result if this research suggested that brand familiarity will positively influence purchase intention, because when consumers are familiar with a certain brand, there will be an intention to purchase that particular product because consumers tend to give attention to brands that they know and familiar with.

\section{Social Influences}

Social influence can be defined as processes in which people indirectly or directly influence feelings, thoughts, and actions to others (Akar, Yüksel, Bulut, 2015). Social influence is related to information about other people that may not happen via direct face-to-face interactions (Akar, et al., 2015). Social influence often occurs when individuals change their minds, behaviours, or feelings in response to their surroundings or their society, it has also been observed that people tend to manipulate their actions and thoughts in order to conform to their groups or their society (Varshneya, Pandey, Das, 2017).

Research on social influence has found that people that are classified into the same social group have a tendency to behave the same as their group (Jacob, Putri, Sihombing, 2020). This kind of behaviour lies in the concept called homophily, in which individuals will try to affiliate themselves with others by displaying the similar or even the same kind of behaviour. (Varshneya, et al., 2017). In other words, the information about a purchase decision of a member of a group towards a certain product will also influenced other group member decision to abandon a certain existing product to shift and purchase the product that other group members used (Younus, et al., 2015).

Wong (2019) stated that social factors such as family, small groups, status, and social roles is known to influenced consumer behaviour, whereas social influence that and individual had may affect another individual to change their attitudes, feelings, and eventually their behaviour towards a product as well. Hence, whenever a product is being used by many people and becomes popular, it will eventually affect other consumers to buy a similar product based on their experience. Wong conducted a research that had a purpose to examine the factors that affecting purchase intention, which one of the factor that is chosen is 
social influence in 2019. This study used smartphone products in Hong Kong as an object and he managed to collect data from approximately 161 respondents with an age range of 18 to 30 years old. The result of his study proved that social influence has a significant positive effect towards consumers' purchase intention on smartphone products. Furthermore, the result also concluded that this range of age consumers will likely use smartphones to communicate with their friends via social media and they will likely decide to purchase a smartphone based on the social influence that they received. When there is a new model issued, they will likely see their friends and relatives have it or through comments on social media, and eventually it may invoke their desire to purchase the product.

Another study conducted by S. M. Sohel Rana, Abdullah Osman, Yusuf Haji Othman (2015) aimed to investigate the factors that influenced purchase intention. They stated that consumer purchase intention represents the consumer desires to purchase a product from a particular shop. It is known that some observations suggested that most consumers shop wouldn't shop on their own and based on previous observations, this research used social influence as one of the independent variables that influenced purchase intention. This study used hypermarket in Malaysia to try to examine the effect that social influence had towards purchase intention. This study was carried out by collecting the questionnaires from 150 respondents and it has proved that social influence plays a significant positive influence towards purchase intention.

One of the main reasons that reference groups engage in word of mouth with individuals, is because they can play an active role in influencing their opinions of others. Hence, their influence sometimes conflicts with or supports particular individual interests and can influence their decision-making process (Rana, et al., 2015). Social influence is known as the effect on an individual based on behaviors of family, friends, co-workers, peers, and individuals or groups that are related to a consumers' behavioral intention that can alter a consumers' thought and action (Kian, et al., 2017). According to Kian, his research on purchase intention in social media websites in Malaysia showed that from the 180 respondents it was proved that social influence has a significant positive influence towards purchase intention. When consumers shoped online through social media, they could be influenced by other social media users on their judgement towards a product and whether or not they should purchased the product. The result also stated that consumers was influenced by comments and opinions that others posted during the purchasing process.

Taking into consideration of all the previous research done regarding product quality and consumers' purchase intention, the following hypothesis can be developed as follows:

H1: Country Image has a positive influence towards Samsung Consumers' Purchase Intention

H2: Product Quality has a positive influence towards Samsung Consumers' Purchase Intention

H3: Brand Familiarity has a positive influence towards Samsung Consumers' Purchase Intention

H4: Social Influence has a positive influence towards Samsung Consumers' Purchase Intention

\section{RESEARCH METHOD}

This research used primary data by using questionnaires as the instrument that can be filled out by respondents individually via online, which are collected from respondents in the age range of 21 to 39 who have used or currently have been using Samsung and were domiciled in Jabodetabek area. The data collected using Likert Scale to measure each indicator, with the range of 1 (strongly disagree) to 5 (strongly agree). According to Joshi, Khale, Chandel, and Pal (2015) Likert Scale is a set of items that researchers offer for a real or hypothetical situation under research, in which the participants are asked to choose their level of agreements arranging from strongly disagree to strongly agree on a metric scale. The combination of statements will reveal the specific attitudes that participants have towards the issue (Joshi, Kale, Chandel \& Pal, 2015).

This research also used SmartPLS to analyse the all the data which are collected by using convenience sampling method. According to Sekaran and Bougie (2016, p. 247), convenience sampling is the accumulation of information from the members of the population of the research which each information is convenient for each individual to share or provide for the research. According Hair, Black, Babin, and Anderson (2019, p. 133) there are some guidelines that needs to be followed in order to determine the 
minimum sample size, but in terms of ratio of observations to variables, the number of sample size has to be at least five times the indicators that is assign to each variables. Therefore, this research used the guideline of ratio of observations to variable to determine the minimum required sample size. The total amount of indicators in this research is 25 , therefore the minimum amount of sample required in this research is 125 . Considering error that might occur, this research attempted to collect more than the minimum required respondents. Therefore, the questionnaires then were distributed to 150 respondents based on the indicators that have been studied in previous researches.

The results of the data obtained from the questionnaire were then processed by SmartPLS for the hypothesis testing. Some of the data in this study were secondary data from the website to support the background of this research phenomenon. The research model is as follows:

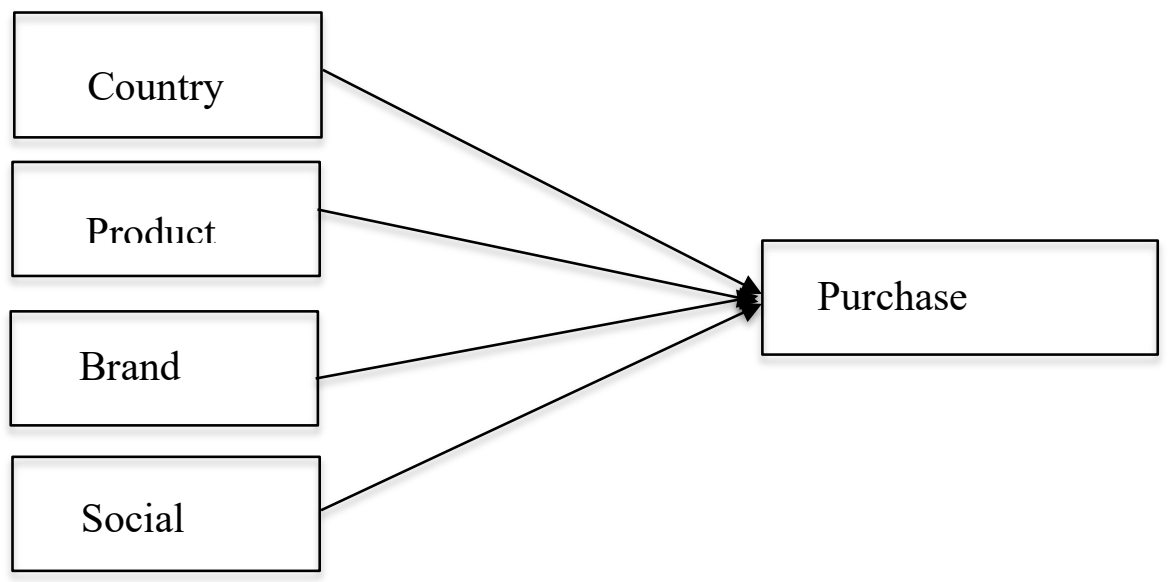

Figure 2.1 Research Model RESULT AND DISCUSSION

The results of data from 150 respondents processed by SMART PLS can be seen in the following tables as the measurement results of descriptive statistics (mean and standard deviation) and inferential statistics. Inferential statistics consist of an outer model (convergent validity, discriminant validity, and construct reliability) and an inner model (multicollinearity, coefficient of determination, and hypothesis testing).

Table 1.3 Descriptive Statistics

\begin{tabular}{cccc}
\hline & \multicolumn{2}{c}{ DESCRIPTIVE STATISTICS } & \\
\hline Variables & Indicators & Mean & Standard Deviation \\
\hline \multirow{2}{*}{ Country Image (COI) } & COI1 & 4.580 & 0.603 \\
& COI2 & 4.507 & 0.608 \\
& COI3 & 4.453 & 0.639 \\
& COI4 & 4.333 & 0.763 \\
& COI5 & 4.267 & 0.789 \\
\hline \multirow{3}{*}{ Product Quality (PRO) } & PRO1 & 4.300 & 0.746 \\
& PRO2 & 3.953 & 0.940 \\
& PRO3 & 3.993 & 0.868 \\
& PRO4 & 4.167 & 0.778 \\
& PRO5 & 4.280 & 0.749 \\
\hline
\end{tabular}




\begin{tabular}{cccc}
\hline & BRA2 & 4.620 & 0.690 \\
Brand Familiarity (BRA) & BRA3 & 4.280 & 1.021 \\
& BRA4 & 4.193 & 0.838 \\
& BRA5 & 4.133 & 0.929 \\
\hline Social Influence (SOC) & SOC1 & 3.513 & 1.305 \\
& SOC2 & 2.947 & 1.326 \\
& SOC3 & 2.947 & 1,389 \\
& SOC4 & 2.747 & 1.461 \\
Purchase Intention & SOC5 & 3.060 & 1.348 \\
(PUR) & PUR1 & 3.807 & 1.153 \\
& PUR2 & 3.833 & 1.092 \\
& PUR3 & 3.667 & 1.159 \\
& PUR4 & 3.600 & 1.238 \\
& PUR5 & 3.613 & 1.285 \\
\hline
\end{tabular}

Source: SmartPLS 3.3.2

In Country Image (COI), each indicator has quite high mean as follows: COI1 (4.580), COI2 (4.507), COI3 (4.453), COI4 (4.333), COI5 (4.267). These all belong to strongly agree and agree categories. The indicator that has the highest mean value is COI1. Meanwhile, the lowest mean value is COI5. In Product Quality (PRO), each indicator has a quite high mean as follows: PRO1 (4.300), PRO2 (3.953), PRO3 (3.993), PRO4 (4.167), PRO5 (4.280). These all belong to strongly agree and agree categories. The indicator that has the highest mean value is PRO1. Meanwhile, the lowest mean value of all indicator in Product Quality is PRO2. In Brand Familiarity (BRA), each indicator has a quite high mean as follows: BRA2 (4.620), BRA3 (4.280), BRA4 (4.193), BRA5 (4.133). These all belong to strongly agree and agree categories. The indicator that has the highest value of mean is BRA2. Meanwhile, the indicator of Brand Familiarity that has the lowest mean value is BRA5. In Social Influences (SOC), each indicator has a quite high mean as follows: SOC1 (3.513), SOC2 (2.947), SOC3 (2.947), SOC4 (2.747), SOC5 (3.060). These all belong to the neutral and agree category. The indicator that has the highest value of mean is SOC1. Meanwhile, the indicator of Social Influence that has the lowest mean value is SOC4. In Purchase Intention (PUR), each indicator has a quite high mean as follows: PUR1 (3.807), PUR2 (3.833), PUR3 (3.667), PUR4 (3.600), PUR5 (3,613). Meanwhile, the indicator of Purchase Intention that has the lowest mean value is PUR4.

Table 1.4 Actual test Convergent Validity

\begin{tabular}{|c|c|c|c|c|c|}
\hline \multicolumn{6}{|c|}{ CONVERGENT VALIDITY } \\
\hline Constructs & \multirow[b]{2}{*}{ Indicators } & \multirow{2}{*}{$\begin{array}{c}\begin{array}{c}\text { Outer } \\
\text { Loadings }\end{array} \\
(0.5-0.7= \\
\text { Acceptable } \\
;>0.7= \\
\text { Valid })\end{array}$} & \multirow[b]{2}{*}{ Validity } & AVE & \multirow[b]{2}{*}{ Results } \\
\hline Requirements & & & & $>0,5$ & \\
\hline \multirow{5}{*}{ Country Image (COI) } & COI1 & 0.771 & Valid & \multirow{5}{*}{0.566} & \multirow{5}{*}{ Valid } \\
\hline & $\mathrm{COI} 2$ & 0.825 & Valid & & \\
\hline & $\mathrm{COI} 3$ & 0.590 & Acceptable & & \\
\hline & $\mathrm{COI} 4$ & 0.751 & Valid & & \\
\hline & COI5 & 0.802 & Valid & & \\
\hline
\end{tabular}




\begin{tabular}{|c|c|c|c|c|c|}
\hline \multirow{5}{*}{ Product Quality (PRO) } & PRO1 & 0.769 & Valid & \multirow{5}{*}{0.544} & \multirow{5}{*}{ Valid } \\
\hline & $\mathrm{PRO} 2$ & 0.649 & Acceptable & & \\
\hline & PRO3 & 0.754 & Valid & & \\
\hline & PRO4 & 0.729 & Valid & & \\
\hline & PRO5 & 0.780 & Valid & & \\
\hline \multirow{4}{*}{ Brand Familiarity (BRA) } & BRA2 & 0.553 & Acceptable & \multirow{4}{*}{0.599} & \multirow{4}{*}{ Valid } \\
\hline & BRA3 & 0.779 & Valid & & \\
\hline & BRA4 & 0.876 & Valid & & \\
\hline & BRA5 & 0.847 & Valid & & \\
\hline \multirow{5}{*}{ Social Influence (SOC) } & SOC1 & 0.724 & Valid & \multirow{5}{*}{0,745} & \multirow{5}{*}{ Valid } \\
\hline & SOC2 & 0.905 & Valid & & \\
\hline & SOC3 & 0.937 & Valid & & \\
\hline & SOC4 & 0.870 & Valid & & \\
\hline & SOC5 & 0.866 & Valid & & \\
\hline \multirow{5}{*}{ Purchase Intention (PUR) } & PUR1 & 0.896 & Valid & \multirow{5}{*}{0,775} & \multirow{5}{*}{ Valid } \\
\hline & PUR2 & 0.818 & Valid & & \\
\hline & PUR3 & 0.901 & Valid & & \\
\hline & PUR4 & 0.908 & Valid & & \\
\hline & PUR5 & 0.875 & Valid & & \\
\hline
\end{tabular}

Source: SmartPLS 3.3.2

Hair et al. (2014, page 103) also stated that a common rule of thumb is the outer loadings of each indicator should exceed 0.708 or at least 0.7 is an acceptable measure. Thus, according to Memon \& Rahman (2014) it is still can be considered acceptable if the outer loading has surpassed 0.5. Furthermore, convergent validity can be assessed by using average variance extracted or commonly known as AVE towards all of the items that associated with a certain construct, this concept is also known as communality (Sarstedt, Ringle, Hair, 2017). Therefore, the results in table 1.4 indicated that all variable has fulfilled the threshold for convergent validity.

Table 1.5 Actual Test Fornell - Lacker

\begin{tabular}{cccccc}
\hline \multicolumn{7}{c}{ FORNELL-LACKER } & & & \\
\hline Variable & BRA & COI & PRO & PUR & SOC \\
BRA & 0.774 & & & & \\
COI & 0.418 & 0.752 & & & \\
PRO & 0.493 & 0.370 & 0.738 & & \\
PUR & 0.551 & 0.265 & 0.622 & 0.880 & \\
SOC & 0.297 & 0.214 & 0.423 & 0.508 & 0.863 \\
\hline
\end{tabular}

Source: SmartPLS 3.3.2

The table above shows that the actual test has produced result that in all of the Fornell-Lacker values indicates discriminant validity amongst all the variables involved within this study are fulfilled. All the variable correlation with its own respective indicators BRA to BRA $(0,774)$, COI to COI $(0,752)$, PRO to 
PRO $(0,738)$, PUR to PUR $(0,880)$, SOC to $\operatorname{SOC}(0,863)$. All variables correlation with the same variables are higher than the correlation with the other variables. This result indicated that discriminant validity has been reached throughout all variables. This result also indicated that respondents can differentiate one variable to other variables.

Table 1.6 Actual Test Reliability

\begin{tabular}{cccc}
\hline & \multicolumn{2}{c}{ CONSTRUCT RELIABILITY } & \\
\hline Variable & $\begin{array}{c}\text { Cronbach's } \\
\text { Alpha }\end{array}$ & $\begin{array}{c}\text { Composite } \\
\text { Reliability }\end{array}$ & Result \\
\hline COI & 0.811 & 0.866 & Reliable \\
PRO & 0.796 & 0.856 & Reliable \\
BRA & 0.775 & 0.854 & Reliable \\
SOC & 0.915 & 0.936 & Reliable \\
PUR & 0.927 & 0.945 & Reliable \\
\hline
\end{tabular}

Source:SmartPLS 3.3.2

Table 1.6 explained that all of the variable's Cronbach's Alpha and Composite Reliability managed to surpass the required threshold of 0.7. Therefore, all of the variables are considered as reliable. This result also indicated that all of the variables are consistent in measuring the concept of each variables.

Table 1.7 Multicollinearity (Inner VIF)

MULTICOLLINEARITY

Independent Variables
Country Image
Product Quality
Brand Familiarity
Social Influence

Inner VIF

1.268

1.538

1.457

Social Influence

1.235

Source: SmartPLS 3.3.2

From the table 4.10, it can be seen that Country Image (COI) has VIF value of 1.268, Product Quality (PRO) has VIF value 1.538, Brand Familiarity (BRA) has VIF value 1.457 and Social Influence (SOC) has VIF 1.457. This result concluded that there are no correlations between all of the variable, therefore the variables on the model should be maintain.

Table 1.8 R-Square and R-Square Adjusted

\begin{tabular}{rcc}
\hline Purchase Intention & R-SQUARE & R-SQUARE ADJUSTED \\
& 0.526 & 0,513 \\
\hline
\end{tabular}

Source: SmartPLS 3.2.2

From the table 4.7 , it can be seen that the $\mathrm{R}^{\wedge} 2$ is 0.526 and the $\mathrm{R}^{\wedge} 2$ adjusted is 0.513 . The data from table 4.11 concluded that the regression model have a moderate explanatory power and the model fits the data well. This result also indicated that $52.6 \%$ of purchase intention can be explained by variables that present in this research. 
Table 1.9 Hypotheses Test

\begin{tabular}{|c|c|c|c|c|c|}
\hline Hypotheses & $\begin{array}{c}\text { Path } \\
\text { Coefficients }\end{array}$ & $\begin{array}{c}\mathrm{t} \text { Statistics } \\
(>1.65)\end{array}$ & $\begin{array}{c}\mathrm{p} \text {-value } \\
(<0.05)\end{array}$ & Results & Conclusion \\
\hline $\begin{array}{c}\text { Country Image } \rightarrow \\
\text { Purchase Intention }\end{array}$ & -0.062 & 0.982 & 0.163 & Insignificant & Unsupported \\
\hline $\begin{array}{c}\text { Product Quality } \rightarrow \\
\text { Purchase Intention }\end{array}$ & 0.378 & 4.162 & 0.000 & Significant & Supported \\
\hline $\begin{array}{c}\text { Brand Familiarity } \\
\rightarrow \text { Purchase } \\
\text { Intention }\end{array}$ & 0.311 & 3.547 & 0.000 & Significant & Supported \\
\hline $\begin{array}{c}\text { Social Influence } \rightarrow \\
\text { Purchase Intention }\end{array}$ & 0.269 & 4.842 & 0.000 & Significant & Supported \\
\hline
\end{tabular}

Source: SmartPLS 3.3.2

From the descriptive statistics, it can be seen that the indicator that has the highest mean value in Country Image is COI1 and it is indicated that the most of the respondent that has an age range of 21-39 particularly the majority in 21-26 and also most respondent in all of the income category with the majority are in between $\mathrm{Rp} 1.000 .000$,- to $\mathrm{Rp} 4.999 .999$,- strongly agreed that Korea is developed in terms of technological advances standpoint. Meanwhile, the lowest mean value is COI5, which stated that majority of the respondents agreed that Korea is reliable. This result in COI5 is not necessary mean that the respondents don't agree that Korea is reliable, but this indicator compared to other indicator in the same variable has the lowest score but it is still considered to be high in terms of the value of the average respondent responses, and this result also tells us that Samsung need to step up in terms of its reliability particularly in their smartphones.

From the descriptive statistics, it can be seen that the indicator that has the highest mean value in Product Quality is PRO1, it means that most of the respondents that has an age range of 21-39 particularly the majority in 21-26 and also most respondent in all of the income category with the majority are in between Rp 1.000.000,- to Rp 4.999.999,-- agreed that Samsung smartphones have good performances, this also tells us that most of the respondents in the millennial category agreed that the performance that Samsung smartphones have is good. It also tells us that Samsung smartphones performance satisfy the millennial consumer and Samsung needs maintain this result. Meanwhile, the lowest mean value of all indicator in Product Quality is PRO2, which stated that the average respondents agreed that Samsung smartphone have a long battery life, but compared to other indicators, this is something that Samsung should be aware of because the average respondents have voted for lower score compared to other indicators. This also interpret that Samsung has a moderate battery life with the average response close to neutral answer and according to this result, Samsung needs to step up their battery life even more to better satisfy millennial consumers that assess this category in their bucket list of smartphones purchasing intention.

From the descriptive statistics, it can be seen that the indicator that has the highest mean value in Brand Familiarity is BRA2, which means that that most of the respondents that has an age range of 21-39 particularly the majority in 21-26 and also most respondent in all of the income category with the majority are in between Rp 1.000.000,- to Rp 4.999.999,-- agreed that they are familiar with Samsung smartphones and this is an advantage that Samsung needs to maintain. Meanwhile, the indicator of brand familiarity that has the lowest mean value is BRA5, which means that the average respondents agreed that they know Samsung smartphone well, but compared to other indicators, Samsung still need to work on this more. This means that Samsung needs to introduce their smartphones more so the consumers in the millennial age range will not just familiar but also know deeper about Samsung smartphone products.

From the descriptive statistics, it can be seen the indicator that has the highest value of mean in Social Influence is SOC1, which means that that most of the respondents that has an age range of 21-39 particularly the majority in 21-26 and also most respondent in all of the income category with the majority are in between Rp 1.000.000,- to Rp 4.999.999,-- agreed that they knew Samsung smartphones from their friends, 
this is an advantage for Samsung because not only the company that works on influencing the potential consumers, but also the consumers also help Samsung to influence other potential consumers to purchase Samsung smartphone, and this needs to be maintain. Meanwhile, the indicator of Social Influence that has the lowest mean value is SOC4, which means that the average respondents agreed that they are not using Samsung to be accepted, so Samsung don't have to emphasize their strategy to give people an impression that they can be accepted if they are using Samsung smartphones and instead put more focus on the influence that friends and relative have to consumers.

From the descriptive statistics, it can be seen the indicator that has the highest value of mean in Purchase Intention is PUR2, which means that that most of the respondents that has an age range of 21-39 particularly the majority in 21-26 and also most respondent in all of the income category with the majority are in between $\mathrm{Rp} 1.000 .000$,- to $\mathrm{Rp} 4.999 .999$,- agreed that they will buy Samsung smartphone in the future, this also indicates that Samsung is moving in the right direction in this indication of buying behavior needs to be maintain by Samsung because the average respondents agreed that they will buy Samsung smartphone in the future and the intention to buy Samsung smartphone has develop in respondents mind. Meanwhile, the indicator of Purchase Intention that has the lowest mean value is PUR4, which means that the average respondents agreed that they have high chance on buying Samsung smartphones, but compared to other indicators, Samsung still needs to work on this more to increase the chance of consumers to purchase Samsung smartphones, but overall these indicators as an average are all belong to the agree category.

The result of this research has proven the first hypotheses regarding Country Image has a positive and significant influence towards Purchase Intention to be false with the t-statistic value is 0.982 . This result is supported by previous research administered by Purwanto and Wibisono (2019), the research that they conducted on purchase intention towards digital camera with 210 respondents explained that Country Image has no significant influence towards purchase intention because when the majority of the respondents are in the productive and young age area for example college students, they have knowledge about the product and when consumers have knowledge about a certain product, they tend to not consider the country of origin image that a product have when they want to purchase the product.

This result also supported by a previous research done by Faraditta and Mudiantono (2015) explained the reasons that allow this hypothesis to be rejected. The respondents who are generally of productive age and most of them are students and workers with a limited sample size will likely to give this outcome. In addition, the thing that can cause this hypothesis to be rejected is the existence of incidents of consumers who already understand regarding the product that he or she is going to buy, so they don't care where the product comes from as long as the product has a good quality. They also stated that consumers that have a high product knowledge are likely to be less affected by country of origin cues in their purchase intention.

The result of this research has proven that the second hypothesis regarding Product Quality has a positive and significant influence towards Purchase Intention is true with the t-statistic value is 4.162. This study is supported by previous study administered by Mirabi, et al. (2015) has proved that product quality has a significant positive influence towards purchase intention. Another previous study done by Purba, et al. (2018) this study showed and also proved that product quality has a significant effect towards consumers' purchase intention. Another past study conducted by Erida and Rangkuti (2017) conclude that product quality has a significant positive effect towards consumers purchase intention.

The result of this research has proven that the third hypothesis regarding Brand Familiarity has a positive and significant influence towards Purchase Intention is true with the t-statistic value is 3.547 . This study is supported by previous studies administered by Das (2015) that brand familiarity has a direct significant effect towards purchase intention. Another previous study done by Viddy, Rafiqoh, Kadang, Angriani (2018) proved that brand familiarity has a significant positive effect towards purchase intention. Another past study conducted by Augusta et al. (2019) suggested that brand familiarity will positively influence purchase intention.

The result of this research has proven that the fourth hypothesis regarding Social Influence has a positive and significant influence towards Purchase Intention is true with the t-statistic value is 4.842 . This study is supported by previous studies administered by (Wong, 2019) the result of this research proved that 
social influence has a significant positive effect towards consumers' purchase intention. Another previous study done by (Rana, et al., 2015) has proved that social influence plays a significant positive influence towards purchase intention. Another previous study conducted by Kian, et al. (2017) on purchase intention proved that social influence has a significant positive influence towards purchase intention.

\section{CONCLUSION}

The results showed that Social Influence had the most significant effect on Purchase Intention with the highest t-statistic of 4,842. Product quality ranks second with a total t-statistic of 4,162, and the last is Brand Familiarity with a t-statistic of 3,547. Furthermore, this study succeeds in concluding that Country Image is considered to have an insignificant effect on Purchase Intention with a total t-statistic of 0.982 which is below the average threshold of 1.65. It was also found that Country Image had no significant and positive effect on Purchase Intention, while other variables of Product Quality, Brand Familiarity, and Social Influence had a positive and significant effect on Purchase Intention. For further research, it can improve the limitations of this study, by adding other determinants and expanding the response in a wider research area in Indonesia to capture the heterogeneity of the the consumers.

\section{REFERENCES}

Akar, E., Yüksel, H. F. \& Bulut, Z. A. (2015). The Impact of Social Influence on the DecisionMaking Process of Sports Consumers on Facebook. Journal of International Applications and Management, 6, (2), 5-27. DOI: 10.5505/iuyd.2015.40412.

Alas, R., Übius, U., Lorents, P., \& Matsak, E. (2017). Corporate Social Responsibility In European And Asian Countries. Jurnal Manajemen Bisnis Dan Inovasi (JMBI) UNSRAT 4(1)

Augusta, D., Mardhiyah, D., Widiastuti, T. (2019). Effect of Country of Origin Image, Product Knowledge, Brand Familiarity to Purchase Intention Korean Cosmetics with Information Seeking as a Mediator Variable: Indonesian Women's Perspective. Dermatology Reports, 11, (1), 7-10. DOI: 10.4081/dr.2019.8014.

Cateora, P. R., Gilly, M. C., Graham, J. L. (2011). International Marketing (15 ${ }^{\text {th }}$ ed.). New York: McGraw-Hill/Irwin.

Das, G. (2015). Linkages between Self-Congruity, Brand Familiarity, Perceived Quality and Purchase Intention: A Study of Fashion Retail Brands. Journal of Global Fashion Marketing, 6, (3), 180-193. DOI: 10.1080/20932685.2015.1032316.

Device Region. (2017). Why are Smartphones Important in Our Daily Life. Retrieved from: https://www.deviceregion.com/smartphones-important-daily-life/.

Etale, L. M., Bingilar, P. F., Ifurueze, M. F. (2016). Market Share and Profitability Relationship: A Study of the Banking Sector in Nigeria. International Journal of Business, Economics and Management, 3, (8), 103-122. DOI: 10.18488/journal.62/2016.3.8/62.8.103.112. 
Erida \& Rangkuti, A. (2017). The Effect of Brand Image, Product Knowledge, and Product Quality on Purchase Intention of Notebook with Discount Price as Moderating Variable. Journal of Business Studies and Management Review, 1, (1), 26-32.

Faraditta, A \& Mudiantono. (2015). Analisis Pengaruh Country of Origin Perception, Perceived Quality dan Consumer Perception terhadap Purchase Intention dengan Brand Image sebagai Variabel Intervening (Studi pada Oli Fastron di Kota Semarang). Diponegoro Journal of Management, 4, (2), 1-10.

Fetai, B., Sadiku-Dushi, N., Ismaili, R. (2017). Measuring The Impact of Extrinsic Cues on Consumers' Purchasing Decision for Food Products. De Gruyter Open, 62, (3), 33-46. DOI: 10.1515/subboec-2017-0012.

Griffin, R. W. \& Pustay, M. W. (2015). International Business: A Managerial Perspective (8 ed.). New Jersey: Pearson.

Hananto, K. (2015). Pengaruh Brand Image dan Country of Origin Image terhadap Minat pembelian Iphone. Parsimonia, 2, (2), 13-22. ISSN: 2355-5483.

Hair, J. F., Black, W. C., Babin, B. J., Anderson, R. E. (2019). Multivariate Data Analysis: (8 ed.). Hampshire: Cengage Learning.

Hair, J., Celsi, M., Money, A, Samouel, P., Page, M. (2016). Essentials of Business Research Methods ( $3^{\text {rd }}$ ed.). New York: Routledge.

Hair, J. F., Hult G. T. M., Ringle, C. M., Sarstedt, M. (2014). A Primer on Partial Least Squares Structural Equation Modeling (PLS-SEM). California: SAGE Publications.

Hair, J. F., Risher, J. J., Sarstedt, M., Ringle, C. M. (2019). When to use and how to report the results of PLS-SEM. Europian Business Review, 31, (1), 2-24. DOI: 10.1108/EBR-11-20180203

Haque, A., Anwar, N., Yasmin, F., Sarwar, A., Ibrahim, Z., Momen, A. (2015). Purchase Intention of Foreign Products: A Study on Bangladeshi Consumer Perspective. SAGE Open, 1-12. DOI: $10.1177 / 2158244015592680$.

Herrero-Crespo, Á., San Martín Gutiérrez, H., Garcia-Salmones, M. del M. (2016). Influence of country image on country brand equity: application to higher education services. International Marketing Review, 33, (5), 691-714. DOI: 10.1108/imr-02-2015-0028.

Hien, N. N., Phuong, N. N., Tran, T. V., Thang, L. D. (2020). The Effect of Country-of-Origin Image on Purchase Intention: The Mediating Role of Brand Image and Brand Evaluation, Management Science Letters, 10, 1205-1212. DOI: 10.5267/j.msl.2019.11.038.

Hill, C. W. L. (2007). International Business: Competing in the Global Marketplace. New York: McGraw-Hill. 
Huang, G. (2016). Moderating Role of Brand Familiarity in Cross-Media Effects: An Information Processing Perspective. Journal of Promotion Management, 22(5), 665-683. DOI: 10.1080/10496491.2016.1154922.

Jacob, M. R., Putri, Y. W., Sihombing, S. O. (2020). Predicting green product purchase: Applying a Cognitive-Affective-Behavior Hierarchy. Jurnal Siasat Bisnis, 24, (2), 87-113. DOI: 10.20885/jsb.vol24.iss2.art1.

Johansson, J. K. (2009). Global Marketing: Foreign entry, Local Marketing, \& Global Management. New York: McGraw-Hill Irwin.

Joshi, A., Kale, S., Chandel, S., Pal, D. K. (2015). Likert Scale: Explored and Explained. British Journal of Applied Science \& Technology, 7, (4), 396-403. DOI: 10.9734/BJAST/2015/14975.

Kamal, S. S. L. B. A. (2019). Research Paradigm and The Philosophical Foundations of a Qualitative Study. PEOPLE: International Journal of Social Sciences, 4, (3), 1386-1394.

Kardes, F. R., Cronley, M. L., Cline, T. W. (2008). Consumer Behavior. Ohio: South-Western Cengage-Learning.

Keegan, W. J., Green, M. C. (2011). Global Marketing (6th ed.). New Jersey: Pearson.

Kian, T. P., Boon, G. H., Fong, S. W. L., Ai, Y. J. (2017). Factors That Influence the Consumer Purchase Intention in Social Media Websites. International Journal of Supply Chain Management, 6, (4), 208-214.

Memon, A. H. \& Rahman, I. A. (2014). SEM-PLS Analysis of Inhibiting Factors of Cost Performance for Large Construction Projects in Malaysia: Perspective of Clients and Consultants. The Scientific World Journal, 1-9. DOI: 10.1155/2014/165158.

Mirabi, V., Akbariyeh, H., Tahmasebifard, H. (2015). A Study of Factors Affecting on Customers Purchase Intention Case Study: The Agencies of Bono Brand Tile in Tehran. Journal of Multidisciplinary Engineering Science and Technology, 2, (1), 267-273. ISSN: 3159-0040.

Mojambo, G. A., Tulung, J. E., \& Saerang, R. T. (2020). The Influence of Top Management Team (TMT) Characteristics Toward Indonesian Banks Financial Performance During The Digital Era (2014-2018). JMBI UNSRAT (Jurnal Ilmiah Manajemen Bisnis dan Inovasi Universitas Sam Ratulangi)., 7(1). Pp1-20

Morwitz, V. (2012). Consumers' Purchase Intentions and their Behavior. Foundations and Trends ${ }^{\circledR}$ in Marketing, 7(3), 181-230. DOI:10.1561/1700000036.

Nugroho, A. R. \& Irena, A. (2017). The Impact of Marketing Mix, Consumer's Characteristics, and Psychological Factors to Consumer's Purchase Intention on Brand "W" in Surabaya. iBuss Management, 5, (1), 55-69. 
Prayogi, S. \& Santosa, A. (2019). The Influence of Product Quality, Prices, and Promotions on Interest in Buying Sri Sulastri's Batik. E-Jurnal Apresiasi Ekonomi, 7, (1), 9-17. DOI: 10.31846/jae.v7i1.121.

Purba, F. D. S., Sulistyarini, E., Sadalia, I. (2018). The Influence of Product Quality on Purchase Intention Through Electronic Words of Mouth in PT. Telkomsel Medan. The 2018 International Conference of Organizational Innovation, KnE Social Sciences, 760-768. DOI 10.18502/kss.v3i10.3421.

Purwanto. E., \& Wibisono, A. (2019). Pengaruh Country of Origin, Word of Mouth, Kualitas Yang Dipersepsikan Terhadap Niat Bel. Jurnal Riset Manajemen dan Bisnis (JRMB), 4(3), 365374. DOI: $10.36226 /$ jrmb.v4i3.278.

Rahim, A., Safin, S. Z., Kheng, L. K., Abas, N., Ali, S. M. (2016). Factors Influencing Purchasing Intention of Smartphone among University Students. Procedia, 37, 245-253.

Rana, S. M. S., Osman, A., Othman, Y. H. (2015). Factors Affecting Purchase Intention of Customers to Shop at Hypermarkets. Mediterranean Journal of Social Sciences, 6, (3), 2015.

Rao, P. S. (2008). International Business Environment. Mumbai: Himalaya Publishing House.

Razak, I., Nirwanto, N., Triatmanto, B. (2016). The Impact of Product Quality and Price on Customer Satisfaction with The Mediator of Customer Value. Journal of Marketing and Consumer Research, 30, 59-68. ISSN: 2422-8451.

Rhee, E. S. \& Jung, W. S. (2018). Brand Familiarity as a Moderating Factor in the Ad and Brand Attitude Relationship and Advertising Appeals. Journal of Marketing Communications, 115. DOI: $10.1080 / 13527266.2018 .1461124$.

Rose, J., Cho, E., Smith, K. R. (2016). Female Consumers' Attitudes and Purchase Intentions toward Intimate Apparel Brands. Fashion, Industry, and Education, 14, (2), 12-23. DOI: 10.7741/fie.2016.14.2.012.

Sarstedt, M., Ringle, C. M., Hair, J.F. (2017). Partial Least Squares Structural Equation Modeling. Handbook of Market Research, 1-40. DOI: 10.1007/978-3-319-05542-8_15-1.

Schiffman, L. G. \& Kanuk, L. L. (2007). Consumer Behavior ( $9^{\text {th }}$ ed.). New Jersey: Pearson Education.

Sekaran, U. \& Bougie, R. (2016). Research Method. United Kingdom: John Wiley \& Sons Ltd.

Sinha, P. K. \& Mittal, V. (2012). International Business. New Delhi: Excel Books Private Limited.

Statcounter. (2020). Mobile Phone Vendor Market Share in Indonesia. Retrieved from: https://gs.statcounter.com/vendor-market-share/mobile/indonesia. 
Statcounter. (2020). Mobile Phone Vendor Market Share World. Retrieved from: https:/gs.statcounter.com/vendor-market-share/mobile/world.

Statista. (2020). Number of Smartphone Users Worldwide from 2016 to 2021. Retrieved from: https://www.statista.com/statistics/330695/number-of-smartphone-users-worldwide/.

Statista. (2020). Share of Population Owning a Mobile Phone in Indonesia from 2010 to 2018. Retrieved from: https:/www.statista.com/statistics/1084069/indonesia-share-of-populationowning-a-mobile-phone/.

Tien, N. H., Phu, P. P., Chi, D. T. P. (2019). The Role of International Marketing in International Business Strategy. International Journal of Research in Marketing Management and Sales, 1, (2), 134-138. ISSN: 2663-3337.

Varshneya, G., Pandey, S. K., Das, G. (2017). Impact of Social Influence and Green Consumption Values on Purchase Intention of Organic Clothing: A Study on Collectivist Developing Economy. Global Business Review, 18, (2), 478-492. DOI:10.1177/0972150916668620.

Viddy, A., Rafiqoh, Angriani, F. (2018). The Effects of Brand Prestige and Brand Familiarity with Brand Awareness on Perceived Quality and Purchase Intention for Users of NMAX Yamaha Motorcycle in East Kalimantan Indonesia. Proceedings of the First International Conference on Materials Engineering and Management, 75, 113-118. DOI: 10.2991/icmemm18.2019.5.

Wong, A. T. (2019). A Study of Purchase Intention on Smartphones of Post 90s in Hong Kong. Asian Social Science, 15, (6), 78-87. DOI: :10.5539/ass.v15n6p78.

Xiao, A., Yang, S., Iqbal, Q. (2018). Factors Affecting Purchase Intentions in Generation Y: An Empirical Evidence from Fast Food Industry in Malaysia. Administrative Sciences, 9(1), 4. DOI:10.3390/admsci9010004.

Xiao, Z., Zhang, J., Li, D., Samutachak, B. (2016). The effect of e-WOM on country image and purchase intention: an empirical study on Korean cosmetic products in China. International Journal of Services Technology and Management, 22, (18), 18-30. DOI: 10.1504/ijstm.2016.077652.

Younus, S., Rasheed, F., Zia, A. (2015). Identifying the Factors Affecting Customer Purchase Intention. Global Journals Inc., 15, (1), 8-14. ISSN: 2249-4588.

Yunus, N. S. N. M \& Rashid, W. E. W. (2016). The Influence of Country-of-origin on Consumer Purchase Intention: The Mobile Phones Brand from China. Procedia Economics and Finance, 37, 343-349. DOI: 10.1016/S2212-5671(16)30135-6. 